ject from many different angles and in the light of opposing schools of thought was stressed by a delegate from South Wales, supported by many others. After seeing the film "Defeat Tuberculosis", he said that, admirable though it was in showing the cure of the disease under ideal clinical conditions, it might nevertheless lull the public, to whom it was designed to be shown, into a false sense of security. Apart from allaying the fear of 'T.B.' in the public mind, it should also have emphasized the urgent necessity for providing the ideal facilities to all who may be in need of them.

The value of the film in teaching medicine, and in particular, surgery, was demonstrated by a professionally made film on "Transplantation of Cornea Autokeratoplasty", as well as by an amateur production by three medical men from the Westminster Hospital on an "Introduction to Acute Inflammation".

Dr. W. T. Astbury (director of the Textile Physics Laboratory, University of Leeds) gave a lecture on "X-Ray Adventures among the Proteins and other Molecular Giants" on September 2. In this talk, garnished with a pleasant humour and illustrated by slides and 'working' models of proteins and fibre molecules, Dr. Astbury emphasized his conviction that the mere imparting of knowledge is not enough. Films should be made which show the quest for ultimate knowledge to be a dramatic and exciting adventure.

During the Conference, delegates inspected an exhibition of projectors and other visual aid equipment; spare projectors were kept busy running amateur-made films, and film strips. The scientific film review, broadeast in the Sunday evening "Science Magazine", interested many. Discussions followed all the lectures, and the Conference ended with a long programme of scientific films.

The Scientific Film Association will publish a full account of the proceedings as soon as possible.

\section{TYROGLYPHID MITES AND HUMAN DISEASE}

CTUDENTS of applied zoology are familiar with $\checkmark$ the damage caused by Tyroglyphid mites to stored products valuable to man. The part they may play in the causation of disease is less well known.

Sir Philip Manson-Bahr and W. J. Muggleton (Lancet, 81, Jan. 20, 1945) direct attention to the possible significance of mites and their eggs in human fæces. Invasion of the human alimentary, urinary and respiratory tracts by tyroglyphid-and sometimes also by tarsonemid-mites has been reported by M. Khalil (Proc. Roy. Soc., Med., 14, Sect. Trop. Dis., $24 ; 1921$ ), who found the eggs of Aleurobius farince in 8 per cent of 130 Cornish miners; by $\mathrm{J}$. Mackenzie (J. Roy. Army Med. Corps, 39, 339 ; 1922), who found $A$. farince and Tarsonemus in recruits suffering from nocturnal enuresis and in one suffering from hæmaturia; and by others who found various mites in human sputum. The evidence about the possible effects of mites in the human alimentary canal has been reviewed up to 1929 by A. Hase (Z. Parasitenkunde, 1,765 ; 1929). Some experts think that such common mites as Glyciphagus domesticus, Aleurobius farince (in meal) and the cheese mites Tyroglyphus siro and $T$. longior can be pathogenic if great numbers are eaten; others deny this. The dermatitis suffered by people who handle mite-infested foodstuffs (Grocer's itch, copra itch) is, however, well known (see Lancet, 351, Sept. 9, 1944). Manson-Bahr has seen dead mites in human fæces from time to time, and during the past year has been finding them with increasing frequency. Recently, eggs showing development from the morula stage to the newly hatched nymph have been found in the frecs of two patients. The mites could not be identified with certainty, but were probably Tyro. glyphus siro. One of the patients had had recurrent diarrhoe and had come from the Isle of Man, where he had eaten much over-ripe cheese. Search for similar mites in the rationed cheese now being sold in Britain has failed. Manson-Bahr and Muggleton conclude that, so far as can be ascertained at present, the presence of mite eggs in human fæces has no pathological significance.

The possible effects of mites upon the respiratory tract are the subject of a paper by E. Soysa and M. D. S. Jayawardena (Brit. Med. J., 1, Jan. 6, 1945) on pulmonary acariasis. During 1943-44 these authors observed a remarkably heavy incidence of bronchial asthma among patients in a hospital of the South-East Asia Command. From January 1942 until June 1944 bronchial asthma was responsible for 48 per cent of all respiratory cases and for 21 per cent of cases invalided out of the Army through this hospital. Some patients showed a high eosinophilia, which in asthma may be, according to Osler, as high as 53 per cent. But the patients rarely gave a family history of asthma or of other allergic symptoms; their eosinophilia was not due to intestinal parasites; drugs commonly given to relieve asthma gave only temporary relief to these patients, and their eosinophilia persisted. Major T. R. Jansen referred the authors to a civilian patient who had asthma with high eosinophilia, and mites were found in his sputum; he made a remarkable recovery after administration of pentavalent arsenic. Referring to the work in Ceylon of H. F. Carter, G. Wedd and V. St. E. D'Abrera (Ind. Med. Gaz., 79, 163; 1944), who recovered species of Tyroglyphus, Tarsonemus, Carpoglyphus, Glyciphagus and Cheyletus, all common in stored products, dust, debris, etc., from 17 out of 28 patients, and found that arsenical treatment reduced both the numbers of the mites and the eosinophilia, Soysa and Jayawardena record their own observations.

The whole problem and its relevant literature is discussed by Soysa and Jayawardena, who found, as others have done, that treatment with arsenical preparations (they used 'carbasone' or 'stovarsol') was satisfactory. While the existing evidence does leave some doubt whether mites can alone cause all the asthma-like symptoms described, the problem requires further investigation. The differential diagnosis between this asthma-like condition and tuberculosis and other obscure and transient respiratory conditions with asthma-like symptoms and eosinophilia (for example, Loeffler's syndrome) may be especially difficult.

That monkeys of the genus Macacus suffer from pulmonary lesions in which mites are found is shown by L. J. Davis (Brit. Med. J., 482, April 7, 1945), who quotes F. D. Weidman ( $J$. Parasit., 2, $37 ; 1915)$ on the acarids which he found in the lungs of Macacus rhesus. Davis found in the lung lesions of a species of Macacus (the species is not stated) mites which probably belonged to the genus Pneumonyssus, and he suggests that these mites may be 
normal ectoparasites of these monkeys, so that monkeys could readily inhale these mites. Experimental infestation of monkeys with them might, he suggests, help us to understand the problem of infestation of the human lung with mites. Davis says that the lesions in the monkey's lung resembled, to the naked eye, the lesions of early tuberculosis. This recalls the similar resemblance to tuberculous lesions of the lesions of organs other than the lung, for example, those of the mesenteric glands, caused by larvæ of the degenerate Arachnid Linguatula. But there is much histological evidence that lesions caused by parasitic nematodes (for example, various Filarioid species) may also resemble those due to tuberculosis. It is elear that the solution of this whole problem will require all the skill of the clinician, the pathologist and the biologist.

G. LAPAGE.

\section{FORTHCOMING EVENTS}

Tuesday, October 9

Royal ANTHRopological INSTITUTt (at 21 Bedford Square, London, W.C.1), at 1.30 p.m. - W. V. Grigson : "The Aboriginal in the don, W.C.1), at

Institution of Chemical Engineres and Chemicat Engineering GROUP (at the Geological Society, Burlington House, Piccadilly London, W.1), at 5.30 p.m.-Dr. E. R. A. Merewether :' "Industria Health-Progress, Contrasts and Fallacies".

Ilitminating Engineering SocietY (at the London School of Hygiene and Tropical Medicine, Keppel Street, London, W.C.1), at 6 p.m.-H. C. Weston : Presidential Address.

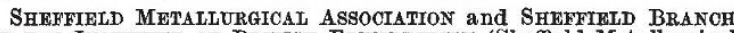
OF THE INSTITUTE OF BRITISH FOUNDRYMEN (Sheffield Metallurgical Club, 198 West Street, Sheffield, 1), at 7.0 p.m.-H. O. Howson : "The Formation of Banded Structures in Horizontal Centrifugal Castings".

\section{Wednesday, October 10}

Roxal Soctety of Medicine, Section of Comiparative Medionne (at 1 Wimpole Street, London, W.1), at 2.15 p.m.-W. A. Pool : "A Plea for the Eradication of Tuberculosis in Cattle in Great Britain" (Presidential Address).

INSTITUTION OF ELECTRICAL ENGINFERS, RADIO SECTION (at Savoy Place, Victoria Embankment, London, W.C.2), at 5.30 p.m.-Mr. A. H. Mumford : Inaugural Address as Chairman.

SocIETY OF CHEMICAI INDUSTRY (joint meeting of the NEWCASTLE SECTION with the ROYAL INSTITUTE OF CHFMISTRY) (in the Chemistry Lecture Theatre, Newcastle-upon-Tyne), at 7 p.m.-Dr. H. Baines "The Choice of Photographic Materials for Scientific Purposes".

INSTIPUTE of WELDING, NORTH LONDON BRANCH (at the SouthWest Essex Technical College, Walthamstow, London, E.17), at 8 p.m. West Eissex Technical Use in Weld Testing"; " Dr. R. J. Barnes : Part 1, "Plant and Equipment"; Dr. S. Torrence: Part 2, "Use and Applications".

\section{Thursday, October II}

ROYAL COLLEGE oF SURgeons (at Lincoln's Inn Fields, Iondon, W.C.2), at 5 p.m.- -Sir Howard Florey, F.R.S.: "The Use of Microorganisms for Therapeutic Purposes" (Lister Memorial Lecture)

INSTITUTION OF ELECTRICAL ENGINEERS, INSTALlations SECTION (at Savoy Place, Victoria Embankment, London, W.C.2), at 5.30 p.m. Mr. Forbes Jackson: Inaugural Address as Chairman.

Society of Chemical. Industry, RoAd and BUmbing Materiats GROOP and LONDON SECTION (at Gas Industry House, 1 Grosveno Place, London, S.W.1), at 6 p.m.-Prof. E. K. Rideal, F.R.S. "Some Physico-chemical Problems in Construction".

AsSOCIATION OF SCIENTIFIO WORKERS, LONDON AREA (in the Caxton Hall, Westminster, London, S.W.1) Hall, Westminster, London, S.W.1), at 7.0 p.m.-Report on Visit of British Men of Scien
Wooster, and others.

ROXAL INSTITUTE OF CHEMISTRX, LONDON AND SOUTH-FASTERN CodNTIES SECTION (at the Public Library, William Street, Slough), at 7.0 p.m.-Dr. J. M. Walter : "Recent Advances in Plastics".

\section{Friday, October 12}

RESEARCH DEFENCE Socrety (at Manson House, Royal Society of Tropical Medicine and Hygiene, 26 Portland Place, London, W.1), at 3.15 p.m.- Sir William Savage: "Public Health and its Debt to

Royal Astronomical Societr (at Burlington House, Piccadilly, London, W.1), at 4.30 p.m.- - Prof. Bengt Edlén: "The Origin of the Emission Lines in the Coronal Spectrum" (George Darwin Lecture).

INSTITUTION OF MFCHANICAI ENGINEERS (Storey's Gate, St. James's Park, London, S.W.1), at 5.30 p.m.-W. G. A. Perring: "The Mechanism of the German Rocket Bomb( V.2)"'( Lantern Lecture).
Institute of WeLding, BIRMinghaM BRANCH (at the James Watt Memorial Institute, Great Charles Street, Birmingham), at 6.30 p.m.Dr. E. G. West: "Developments in the Welding of Aluminium

Society of Chemical Industry, South WaLes Section (at the Royal Institution, Swansea), at 6.30 p.m.-Mr. F. Gill : "New Physical Methods in Examining Petroleum Products".

British Association of Chamists, St. Helens Section (at the "C.M.C.A. Buildings, St. Helens), at 7.30. p.m.-Mr. H. Pritchard:

\section{Thursday, October II-Thursday, October 25}

ELECTRICAL ASSOCIATION FOR WOMEN. Twenty-first Birthday Celebrations, at Dorland Hall, Lower Regent Street, London, S.W.1. October 11, at 11 a.m.-Opening by Duchess of Kent.

October 12, at 2.30 p.m.- Sir Robert Watson-Watt, C.B., F.R.S.: "Women and Wireless." Dr, Kathleen Lonsdale, F.R.S.: "A Woman Physicist Look" October 12 and 13 . Annual Conference of the Women's Engineering
Society. Miss M. M. Partridge: "The Next Twenty-one Years" Society. Miss M. M.

\section{APPOINTMENTS VACANT}

APPLICATIONS are invited for the following appointments on or before the dates mentioned

SCIENTIFIC OFFICER FOR POTATO INVESTIgations at the National Institute for Agricultural Botany, Huntingdon Road, CambridgeThe Secretary (Oct. 10).

A LECTURRR and an Assistant LECTURER IN ZOOLOgY in the University of Birmingham-The Secretary (Oct. 13)

EDUCATIONAL ADMINISTRATIVE OFFICERs (male and female) to deal with universities, adult education, technical colleges, youth activities, and other aspects of the control of German education in the British Zone of Occupation-Appointments Department, Ministry of Labour and National Service, Sardinia Street, London, W.C.2, quoting Ref. No. 0.S.1113 (Oct. 15)

Teacher of MEchanical ENGINewring SubJhots, and a Teacher of PHYsics, at the Acton Technical College, High Street, Acton, London, W.3-The Principal (Oct. 15).

IECTURER IN INoRganio CHEMIsTRy in University College, Nottingham-The Registrar (Oct. 20).

IAOCTURER IN ORGANIC CHEMISTRY at the City of Liverpool Technical College-The Clerk to the Local Education Authority (Oct. 20).

LECTORER IN GENERAL ENGINEERING SUBJECTS, and a LECTURER IN EngINERRING Mathematios, in the Merchant Venturers' Technical College, Bristol-The Principal (Oct. 20).

ChIEF SUPERINTENDING ENGINEER (Ref. No. C.2840.XA), ASSISTANT ChImF ENGINERr (Ref. No. C. 2841.XA), MECHANICAL ENGINEer (Ref. No. C.2842.XA), for a paper mill in India-The Ministry of Labour and National'Service (Appointments Department), Technical and Scientifle Register, Room 670, York House, Kingsway, London, W.C.2 (Oct. 22)

LECTURER IN PHILOSOPHY in the University of Birmingham-The Secretary (Oct. 27).

HARBOUR ENGINEER for harbour construction and maintenance, for the Sudan Railways-The Ministry of Labour and National Service, Appointments Department, Technical and Scientific Register, Room 670, York

DIRECTOR OF THE BRITISH ELECTRICAL AND ALIIED INDUSTRIES RESEARCH ASSOCIATION, 15 Savoy Street, London, W.C.2-The Chairman (Nov. 16)

READER IN PUBLIC HEALTH in the University of London at the London School of Hygiene and Tropical Medicine-The Academic Registrar, University of London, Richmond, Surrey (Jan. 29, 1946). CHAIR OF NATURAI'PHILOSOPHY in the University of AberdeenThe Secretary (Feb. 15, 1946).

Chair of Experimental Physics and Theoretical Mechanics at Istanbul University-The British Council (Appointments Department), 3 Hanover Street, London, W.1.

Chair of Mechastcal Engingering, Chatr of Engineming

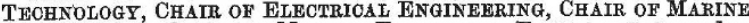
EngINEERING, Chatr of MARINE ELECTrICAL ENGINEERING, and a ChaIR OF TRLEgRAPHY AND TELEPHONY, in the Technical University, Istanbul-The British Council (Appointments Department), 3 Hanover Street, London, W.1.

CHAIR OF PHYSIOS, and CHAIR OF CHPMISTRY, in Ankara University Council (Appointments Department), 3 Hanover Street, London, W.1.

IABORATORY STEWARD to take charge of animal house at a cancer research laboratory-The Director of Research, Glasgow Royal Cancer Hospital, 132 Hill Street, Glasgow, C.3.

LACTURER in Psychology at the Furzedown Training College, Welham Road, London, S.W.17-The Principal.

A Lecturar in Chemistry, and a Lecturer in Blology, at the Polytechnic, Regent Street, London, W.1-The Director of Education.

Leoturer IN Sociologr at Bishop Otter College, Chichester-The Principal.

TEAOHER (man or woman) OF BroLOGY at the Wolverhampton and Staffordshire Technical College-The Clerk to the Governors, Education Offices, North Street, Wolverhampton. 